\title{
Students' Perceptions of the Use of Zoom and WhatsApp in ELT Amidst Covid19 Pandemic
}

\author{
Suadi ${ }^{1}$ \\ ${ }^{1}$ Corresponding author, Sekolah Tinggi Agama Islam Negeri Mandailing Natal, Indonesia; \\ $\underline{\text { suadi@ stain-madina.ac.id }}$
}

Received: December 23, $2020 \quad$ Accepted: January 22, $2021 \quad$ Published: January 22, 2021

\begin{abstract}
During the Covid19 pandemic, online learning platforms are solutions to sustain the English Language Teaching (ELT). It is an appropriate platforms option for lecturers to deliver the course materials amidst the covid19 outbreak. Some of the most frequently used platforms are Zoom and WhatsApp. The purpose of this study is to describe the EFL university students' perceptions of the use of Zoom and WhatsApp in ELT. A virtual class in form of Zoom and WhatsApp was created to enable students to remotely attend the class and at the same time to keep in line with the covid19 health protocol. This study involved 53 students as respondents. The data were obtained through onlinebased questionnaire and were analyzed based on a mixed method approach by combining quantitative and qualitative method. The result revealed that the virtual class of ELT for EFL University students in form of Zoom and WhatsApp was considered positive by the learners. Although the availability and slow speed internet connection were being problems to use them in ELT, they were also rated effective and efficient in terms of time, place and expense. Moreover, learners agreed that those two online platforms can help them to improve language skills and to reduce shyness in virtual class interaction.
\end{abstract}

Keywords: Students' Perception; Teaching Learning English; WhatsApp; Zoom

To cite this article: Suadi, S. (2021). Students' perceptions of the use of Zoom and Whatsapp in ELT amidst Covid-19 pandemic. SALEE: Study of Applied Linguistics and English

Education, 2(01). https://doi.org/10.35961/salee.v2i01.212

DOI: $10.35961 /$ salee.v2i01.212 


\section{Introduction}

The presence of Covid19 outbreak since by the end of year 2019 suddenly revolutionizes all aspects in the world includes the education aspect. It is quite shocking that the world faces a condition never exists before where all activities are restricted locked down and full of awareness. The virus is rapidly contagious via airborne, droplets, and traces left by sufferers on any medium, commonly on surface of things mainly around public facilities. This condition is worsened by the fact where the numbers of suspect and death toll astonishingly rockets uncontrollable. This happen all the world and Indonesia.

Those above realities force the government to anticipate via raising social awareness and inviting people to stay away from Covid19 threats. One of the government's policies is work from home (WFH) by introducing online learning system in education aspect. This policy addresses people (lecturers, students) either to sustain learning process as usual by different way (namely online system) and to reduce the virus spreads via remote learning and social distancing.

This condition insists either lecturers or learners to master digital technology. Bagata et.al (2020, pp.1) described the reality of covid-19 drives lecturers and learners to acquire technology to use it in teaching learning process. He added that online learning technology has important role to succeed the teaching learning process itself. In further words, it implied that a lecturer must master the online technology so that can manage the class atmosphere, deliver the course material and develops students' enthusiasm in virtual class very well. At the same time, learners are obliged to master those online platforms in order they can learn the materials in virtual class as they have felt in previously in real classroom setting.

Beside the factor of covid19 pandemic, the emergency of the utilization of online platforms in teaching learning process is also initiated based on the fact that learners at recent time are digital natives. They are getting accustomed to use smartphones and surrounded by online applications since childhood. Cakrawati (2017, pp.29) illustrated that when a teacher or lecturer uses a technology in English teaching learning, it effectively awakens students' interest and enthusiasm due to they are digital natives.

By those both platforms, learners can not only involve in online learning in real time synchronously, but also can be active in virtual class asynchronously without being hindered by the time, place and any other conditions. The use of these two platforms also offers low cost as stated by Smart and Cappel $(2006$, pp.201, 203) the use of online learning has potential cost saving and it also offers more cost effective to conduct learning and deliver instructions.

The researcher, in this context, used Zoom and WhatsApp in English teaching learning process at STAIN Mandailing Natal. The researcher had some reasons to justify the use of combination of Zoom and WhatsApp as follows: (1) Zoom is used to keep learners having real-time, face-to-face or realistic experience in virtual class, (2) WhatsApp is applied to accommodate learners' participation, feedback and achievement through giving comments, questions and discussion. In addition, WhatsApp provides space for posting the materials which are restricted in Zoom. Moreover, WhatsApp also has role as the terminal of submitting the assignment such as written assignments, oral assignment (audio) or even individual speaking recording assignment (video). Moreover, the use of WhatsApp offers a 
very low cost as stated by Wahyuni et.al (2020, pp.316) besides it is cheap with low internet data consumption, it also has features for text messaging, pictures, and audio.

There were some interesting facts during the online learning implementation that it steered the researcher to initiate doing this research. Campus of STAIN Mandailing Natal is located at a remote area; it is far away from the capital city with very good facilities to support the online learning as offered in big city such as Medan and Padang or even Jakarta. The lack of sufficient facilities in STAIN Mandailing Natal turns into problems such as slow speed internet connection, low class economy and declining the students' readiness to operate the online platforms. This drove the researcher to do a study on how the learners perceive the condition they face during online learning by using Zoom and WhatsApp amidst Covid19 pandemic.

The other important thing to do in this study was the learners' role to evaluate online learning whereby they had involved and had experiences in it. They involved to evaluate by giving perceptions rating how effective and what the difficulties during the online learning process amidst Covid19 outbreak. This is suitable with what Chen (2003) emphasized that learners' perceptions have significant role in the process of evaluation on how effective the teaching learning itself.

This research was focused to reveal the perception of learners of the use of Zoom and WhatsApp platforms in English language teaching and learning. It was carried out during the first semester ranging from September to December academic year 2020-2021. This research took place at STAIN Mandailing Natal and followed by 53 first semester students, male and female, who had conducted online English learning by Zoom and WhatsApp. In addition, 29 students are from the Department of Sharia Business Management and the rest, 24 learners are from the Department of Sharia Banking. The data of perceptions were obtained via online-based questionnaires.

\subsection{Literary Review}

Online learning system is inevitably used by the most either lecturers or learners amidst Covid19 pandemic. Alvarez (2001) stated that online learning gives students a chance to break the limitations generally found in a traditional classroom setting, whereby the performances of learners are evaluated via test assessment and they hesitate to express their thoughts and difficulties they have in class directly to the lecturer. It appears that online learning gives a broad freedom of learning style. Learners will have a self-confidence to deliver the obstacles they face in virtual class to lecturer via online, a situation where they physically never do when they meet their lecturer via face-to-face in real class setting.

In advance, online learning must be much developed to fulfil different learning approaches and to accommodate students' needs with different background. Referring to Armstrong (2011, pp.223) to build an environment of effective online learning is challenging. Online education has chance to be improved and increased as an educational tool. Moreover, online learning system offers a great number of potentials and chances to succeed the language learning.

Two of many online learning platforms are Zoom and WhatsApp. Zoom can act far better than video call as WhatsApp offers. WhatsApp features on video call are limited for several users. Compare to Zoom. It can accommodate users in a single meeting to gather $10-500$ users. Even more, it is quite effective and efficient to gather learners around 20 to 40 learners 
in a virtual class meeting. Abdillah, \& Darma (2020) in Wan Hassan et.al (2020, pp.5854) defined Zoom as a media of face-to-face or two ways broadcasting platform that can be used to interact directly like in real meeting face to face setting. It provides everyone the special facility to participate in meeting by clicking a link or room number. This platform has a myriad of advantages such as saving time, low cost and positive impact environment. Students and lecturers will be easily writing and discussing during the class as they feel in traditional classroom setting.

For short, Zoom allows the users, in this context lecturers and learners, to be acting freely as they do in real conventional classroom. It opens opportunity for learners to give feedback directly to lecturer face to face. The lecturer also can organize the online class via zoom as he/she wants synchronizing with the course materials he delivers.

Other platform offers flexibility for online learning beside Zoom is WhatsApp. Mistar (2016, pp.96) asserted that technology plays marvellous role and gives great impact to mankind's lives, including the use of WhatsApp platform in the field of education that offers positive feedback in the learning development.

This platform is not only offering new feature of sending message, but also has cool features beside sending written text message, namely photo sharing, video, audio (voice) and document (files). Susilawati and Supriyatno (2020, pp.853) argued that a survey declared $90 \%$ of learners and lecturers use WhatsApp in their everyday activities, including in teaching learning activities. They stated that WhatsApp has a large number of features which can be utilized for communication powered by internet connection. Features available in WhatsApp are gallery for posting photos, contact persons, camera for photograph, voice note, maps, sending documents and videos.

Those features which are supplied by WhatsApp can complete the features Zoom platform does not provide. These two platforms completely considered complete to one another to be acting as the online learning tools in order the online class atmosphere is like in a traditional classroom setting. This virtual class atmosphere that is supported by sophisticated features in online learning tools will engage learner to be more active to involve. Yee (2011, pp.17) pointed out that the quality of learning is determined on how a student gets involved to interact in learning class environment.

The use of online learning tools Zoom and WhatsApp must be evaluated to reveal the effectiveness after its implementation. The best way to do it is by involving students by allowing them to give their own perception on online learning tools as they have used in their virtual class setting. Agung, et.al (2020, pp.227) emphasized that students' perception on online learning will be developed opinion because they have concrete experience about it. This is in line with Bagata, et.al (2020, pp.3) stated that perception is primer psychological human in responding to the existence of many things around them.

In terms of students' perception on the utilization of Zoom and WhatsApp in Online English learning system, there are studies done by researchers. Mistar (2016) did a research by involving 20 respondents to investigate the students' perception on the use of whatsapp as a learning tool in ESL classroom. The result shared that WhatsApp helps students to learn language better and stimulated them to be proficient. This study has a gap with the current one namely in point of focus whereby this previous study on the use of WhatsApp, meanwhile the successor study focused on combination of Zoom and WhatsApp and involving 53 respondents. 
A study also had been done by Cakrawati (2017) emphasized on the students' perception on the use of online learning platforms in ELF classroom. Her study revealed positive attitude by learners on the use of online platforms in learning English. The gap with this current study is the number of respondents and the online platforms to be rated. She did a study focusing on perception on the use of Edmodo and Quipper by involving 40 respondents via closedended questionnaire and interview, this study focused on Zoom and WhatsApp by involving 53 respondents via closed-ended questionnaire and open-ended questionnaire.

Wijayanti and Gunawan (2018) conducted a study on students' perception on the utilization of WhatsApp for Vocabulary teaching and learning. Their study revealed that online class by using WhatsApp is considered positive by the students. The gap between previous study with this current study is as follows; (1) the previous study only focused on WhatsApp as online learning tool, meanwhile this current study focused on the use of combination of Zoom and WhatsApp. Moreover, (2) previous study used paper-based questionnaire to obtain the data, meanwhile this current study used online-based questionnaire, and it was completed by open-ended questionnaire to clarify and to confirm the data obtained from closed-ended questionnaire.

Other predecessor study had been carried out by Khusniyah (2020) to reveal Teacher's Perception on SQ4R in English Reading Comprehension Learning Using Zoom Application. The result showed that the use of zoom in learning English especially in reading comprehension gives positive attitude. Although there some similarities, but to compare to current study, the essence of the focus is different. Previous study focused on teachers' perception on the use of Zoom, this current study focused on learners' perception on the use of Zoom and WhatsApp.

The theories and the studies obviously mentioned above indicate that lecturers, together with learners can utilize online learning tools, especially Zoom and WhatsApp in ELT. Therefore, this study attempted to investigate the gap found among the previous studies as novelty, namely students' perception of the utilization of Zoom and WhatsApp in ELT amidst Covid19 pandemic.

\subsection{Research Objective}

This study attempted to investigate students' perception of the use of Zoom and WhatsApp in ELT amidst Covid10 pandemic. In addition, this study was expected to reveal the advantages and disadvantages regarding the use of Zoom and WhatsApp in English Language Teaching.

\section{Method}

This study used a mixed method approach. Creswell (2014) asserted that mixed method research is an approach to inquiry by combining both qualitative and quantitative methods to discover a more complete understanding of a study than using a single approach. Creswell (2014) affirmed the difference between qualitative and quantitative is in the domain of using words (qualitative or using open-ended questions) rather than using numbers (quantitative or using closed-ended questions). It was suitable with this research's needs. Therefore, researcher used closed-ended questionnaire and open-ended questionnaire. Farooq (2018, pp.54) stated that Open-ended questions allow respondents to give responses based on their 
own opinion, while as closed-ended questions restricts the respondents with a grid of questions from which they have to choose to answer the question.

By quantitative method, the researcher collected and analyzed the data statistically based on result of closed-ended questionnaire, followed by interpreting the result into a description. By qualitative method, the researcher was allowed to strengthen the previous quantitative result by analyzing the result of open-ended questionnaire into a depth-explanation and description.

\subsection{Data Sources}

The data of students' perception of the use of Zoom and WhatsApp in ELT obtained from online-based questionnaire. They were administered via Google form due to more effective, time efficiency, low cost and to obey Covid19 health protocol. The respondents were 53 male-female first semester students from the Department of Sharia Banking (24 students) and the Department of Sharia Business Management (29 students) in STAIN Mandailing Natal.

\subsection{Data Collection}

In data collection, the researcher used closed-ended questionnaire and open-ended questionnaire. Closed-ended questionnaire consisted of 12 questions using a four-likert scale. It was adapted and simplified from the questionnaire model that was used in previous study conducted by Cakrawati (2017). It was used due to the simple quantification to extract the data of students' perception into numbers and percentages. The phases of data collection from questionnaire for quantitative needs as follows (1) the researcher created the questions of closed-ended questionnaire to lead the respondents giving a certain perception of the use of Zoom and WhatsApp as they had faced in Online English learning, (2) each question has four choices indicating specific students' perception on the use of Zoom and WhatsApp in ELT (3) the questionnaire was organized and posted in Google form (4) giving questionnaire to respondents who had online English learning background. (5) The result of questionnaire automatically appeared in answer sheet in form of a computed excel data.

The phases of collecting data for open-ended questionnaire as follows (1) the researcher created the questions to allow the respondent to give in-depth opinion regarding the use of Zoom and WhatsApp in online English learning, particularly about the advantages and disadvantages of the use of Zoom and WhatsApp in online English learning. (2) Questions of interview were posted in google form together along with the questionnaire. (3) The answers of interview automatically appeared in answer sheet in form of unstructured opinions.

\subsection{Data Analysis}

The statistical data obtained from questionnaire were computed automatically to result the detailed percentage for each perception regarding the use of Zoom and WhatsApp in ELT. Then the statistical data were interpreted with broad description and elaboration. Each of 12 questions in questionnaire had four choices for respondent to express a certain perception of 
the use of Zoom and WhatsApp in ELT namely: (1) strongly agree, (2) agree, (3) neutral, (4) disagree. Each choice represents the students' specific perception. The perception drove to the tendency of the use of Zoom and WhatsApp whether sharing positive or negative attitudes.

Then, results of open-ended questionnaire clarified and confirmed the results of closedended questionnaire. Result of open-ended questionnaire allowed respondent to express opinion freely regarding the use of Zoom and WhatsApp in realistic online English learning. The perception from each particular question determined the advantages and disadvantages of implementing the online learning, mainly by using Zoom and WhatsApp.

\section{Finding and Discussion}

\subsection{Findings}

In this section, the researcher provides and discusses the finding that is steered by research objective to investigate the students' perception of the use of Zoom and WhatsApp in ELT amidst Covid19 outbreak. The discussion is presented through the interpretation of the results of closed-ended questionnaire shown in the tables in form of simple quantification and percentage, then confirmed and elaborated along with the findings of open-ended questionnaire. The results of the study were obtained from 53 respondents consisting of 24 students of Sharia Banking Department and 29 students of Sharia Business Management. The students had used either Zoom or WhatsApp in English virtual classroom ranging from September to December 2020. In comprehensive findings, the students rated positive for the use of Zoom and WhatsApp in ELT.

In order to answer the research problem that was formulated in the research objective, the findings from students' questionnaire are presented in Table 1, Table 2 and Table 3 as follows:

Table 1. Students' perception of the use of Zoom and WhatsApp in ELT

\begin{tabular}{llllll}
\hline No & \multicolumn{1}{c}{ Question } & $\begin{array}{c}\text { Strongly } \\
\text { agree }\end{array}$ & Agree & Neutral & Disagree \\
\hline $\mathbf{1}$ & $\begin{array}{l}\text { I think the use of Zoom and WhatsApp } \\
\text { can help me to understand English } \\
\text { material better. }\end{array}$ & $11.3 \%$ & $32.1 \%$ & $37.7 \%$ & $18.9 \%$ \\
\hline $\mathbf{2}$ & $\begin{array}{l}\text { I think the use of Zoom and WhatsApp } \\
\text { is strategic for learning English, } \\
\text { especially for discussion and question- } \\
\text { answer. }\end{array}$ & & & & \\
\hline $\mathbf{3}$ & $\begin{array}{l}\text { I think the use of Zoom and WhatsApp } \\
\text { is strategic for learning English, } \\
\text { especially for submitting the } \\
\text { assignment. }\end{array}$ & & $32.11 .3 \%$ & $32.1 \%$ & $26.4 \%$ \\
\hline $\mathbf{4}$ & $\begin{array}{l}\text { I think the use of Zoom and WhatsApp } \\
\text { in learning English process is saving } \\
\text { time, energy and low cost. }\end{array}$ & $18.9 \%$ & $35.8 \%$ & $20.8 \%$ & $24.5 \%$ \\
\hline
\end{tabular}

Note: Strongly Agree $=$ A Agree $=$ A Neutral $=$ N Disagree $=D$ 
Table 1 in question 1 shows that most students $(\mathrm{SA}=11.3 \% \mathrm{~A}=32.1 \%)$ in this research considered positive for the use of Zoom and WhatsApp to understand English better. Although there are also a great number of students who stated neutral $(\mathrm{N}=37.7 \%)$, most students dominantly perceived that the use of Zoom and WhatsApp is helpful in learning English $(\mathrm{SA}+\mathrm{A}=43.4 \%)$. The rest respondents (18.9\%) stated disagree. disagree perception was small percentage to compare to percentage who rated positive. The conclusion is the use of Zoom and WhatsApp was rated positive an attitude by learners in terms of it is helpful in learning English.

Students rated the use of Zoom and WhatsApp positive opinion for learning English especially for discussion and question-answer session as shown in table 1 question 2 ( $\mathrm{SA}=$ $9.4 \%$ and $\mathrm{A}=32.1 \%$ total $=41.5 \%$ ). Although in the previous question (question 1 ) students rated lower negative on the use of Zoom and WhatsApp can help to understand English, $\mathrm{i}$ contrast to question 2 whereby students considered it is higher negative $(26.4 \%)$ and neutral $(32.1 \%)$. It means that the use of Zoom and WhatsApp is more strategic to support comprehending English materials than for discussion and question-answer. It proves that online class setting can be acting just like traditional class setting.

Interestingly, students gave positive rate for the use of Zoom and WhatsApp in ELT especially in submitting the assignment $(\mathrm{SA}=11.3 \%$ and $\mathrm{A}=43.4 \%)$. If we see in detail the percentage in question 3 , it makes sense that students have flexible time and mobility to do the assignment and they can submit it anywhere and whenever. In contrast to who rated disagree (13.2\%). Moreover, students rated neutral (32.1\%) quite high and it indicates they stand in the middle: between they got advantages and they got difficulties in using Zoom and WhatsApp to submit the assignment.

Surprisingly, in question 4 , students considered positive attitudes ( $\mathrm{SA}=18.9 \%$ and $\mathrm{A}=$ $35.8 \%$ total: $54.7 \%$ ) on the use of Zoom and WhatsApp can save time and energy and it offers low cost. It is adequate attractive that the students also rated negative with high percentage (24.5). They do not believe that Zoom and WhatsApp can save time, energy and low cost. Opinion on neutral was $20.8 \%$. Although it is smaller than number of students who rated positive and negative, it implied that saving time and energy and low cost shows that the use of Zoom and WhatsApp in ELT is not applicable. Their perceptions considered sometimes it is true, sometimes it is not.

Table 2. Students' perception of the use of Zoom and WhatsApp in ELT

\begin{tabular}{clcccc}
\hline No & \multicolumn{1}{c}{ Question } & $\begin{array}{c}\text { Strongly } \\
\text { agree }\end{array}$ & Agree & Neutral & Disagree \\
\hline $\mathbf{5}$ & $\begin{array}{l}\text { I think the use of Zoom and WhatsApp } \\
\text { in ELT can help students to practice } \\
\text { English }\end{array}$ & $7.5 \%$ & $43.4 \%$ & $24.5 \%$ & $24.5 \%$ \\
\hline $\mathbf{6}$ & $\begin{array}{l}\text { I think the use of Zoom and WhatsApp } \\
\text { can help the students to improve their } \\
\text { vocabularies mastery }\end{array}$ & $7.5 \%$ & $37.5 \%$ & $26.4 \%$ & $28.3 \%$ \\
\hline $\mathbf{7}$ & $\begin{array}{l}\text { I think the use of Zoom and WhatsApp } \\
\text { can eliminate hesitation/un- } \\
\text { confidence to practice English }\end{array}$ & $17 \%$ & $54.7 \%$ & $18.9 \%$ & $9.4 \%$ \\
\hline
\end{tabular}


8 I think the use of Zoom and WhatsApp

makes the teaching learning English $\quad 11.3 \% \quad 34 \% \quad 18.9 \% \quad 35.8 \%$ more effective.

Note: Strongly Agree $=$ A Agree $=$ A Neutral $=$ N Disagree $=D$

Table 2 question 5 shows that students strongly agree (7.5\%) and agree (43.4\%) the use of Zoom and WhatsApp can help them to practice English. It is reasonable where they practice instructed English speaking via video recording. Then, they submit the video recording of their speaking performance to WhatsApp group. In this context, they are safe from performing in front of their classmates in realistic class setting. If so, they will be nervous, unconfident and getting stuck. By this way, they freely can express anything based on the given topic to speak English. They also rated negative (DA $=24.5 \%)$. It implies they feel better to practice English via face-to-face in traditional class setting. Students also chose neutral with quite high percentage (24.5).

Most of students gave positive attitudes $(\mathrm{SA}=7.5 \%$ and $\mathrm{A}=37.5 \%)$ on question 6 , namely the use of Zoom and WhatsApp can help them to improve their vocabularies mastery. This is based on their experience in online learning that faced many English terms used in the features, either Zoom or WhatsApp. Then it also offered chance to allow them to access English materials in internet such as Google. A small number of them rated negative (28.3\%). In this context, perhaps they found difficulties to access via Google and more convenient by improving vocabulary mastery directly in the classroom setting. Moreover, only $26.4 \%$ of the students gave neutral option.

Most students perceived positive attitudes $(\mathrm{SA}=17 \%$ and $\mathrm{A}=54.7 \%)$ in question 7 that use of Zoom and WhatsApp can reduce hesitation or un-confidence feeling to practice English. Most of students are inactive who are passive in class interaction and participation. This statistical data proved that it can be overcome by using Zoom and WhatsApp platform in ELT. The justification is that they can practice freely without being nervous or being bullied by their classmates as they receive in non-online class atmosphere. Only $9.4 \%$ of students considered negative opinion.

In terms of the use of Zoom and WhatsApp makes learning English more effective as shown in question 8 , most students expressed positive attitude by percentage $11.3 \%$ strongly agree and $34 \%$ agree. Total percentage of strongly agree and agree is $44.3 \%$. It is greater than the percentage of negative $35.8 \%$ or neutral $18.9 \%$. In general picture, based on this closedended questionnaire, the use of Zoom and WhatsApp in ELT makes learning English more effective although in reality as shown in above table, the negative attitude is higher than other previous questions.

Table 3. Students' perception of the use of Zoom and WhatsApp in ELT

\begin{tabular}{cccccc}
\hline No & \multicolumn{1}{c}{ Question } & $\begin{array}{c}\text { Strongly } \\
\text { agree }\end{array}$ & Agree & Neutral & Disagree \\
\hline 9 & $\begin{array}{l}\text { I think the use of Zoom and WhatsApp } \\
\text { in ELT facilitates the interaction and } \\
\text { communication between lecturer and } \\
\text { students far better. }\end{array}$ & $13.2 \%$ & $41.5 \%$ & $26.4 \%$ & $18.9 \%$ \\
\hline
\end{tabular}




\begin{tabular}{llllll}
\hline $\mathbf{1 0}$ & $\begin{array}{l}\text { I think the use of Zoom and WhatsApp } \\
\text { is very difficult, mainly by smartphone }\end{array}$ & $20.8 \%$ & $35.8 \%$ & $28.3 \%$ & $15.1 \%$ \\
\hline $\mathbf{1 1}$ & $\begin{array}{l}\text { I think the use of Zoom and WhatsApp } \\
\text { is very difficult due to low-speed } \\
\text { internet connection }\end{array}$ & $35.8 \%$ & $47.2 \%$ & $13.2 \%$ & $3.8 \%$ \\
\hline $\mathbf{1 2}$ & $\begin{array}{l}\text { I think the use of Zoom and WhatsApp } \\
\text { is very difficult because of low } \\
\text { economy. }\end{array}$ & $34 \%$ & $43.4 \%$ & $20.8 \%$ & $1.8 \%$ \\
\hline
\end{tabular}

Note: Strongly Agree $=$ A Agree $=$ A Neutral $=$ N Disagree $=$ D

Table 3 question 9 displays the most students decided positive ( $\mathrm{SA}=13.2 \%$ and $\mathrm{A}=$ $41.1 \%$ total $54.7 \%$ ) on the use of Zoom and WhatsApp can facilitate the interaction and communication between lecturer and students. By these two online platforms, students and lecturer are allowed to interact and to communicate with high frequency without being limited by time, place and even cost mainly by using WhatsApp. Student can consult, ask or even confirm anything related to English course materials. At the same time, a lecturer can accommodate them with flexible ways.

Students' perception in question 10 is quite shocking. They considered positive perception on the difficulties of the use of Zoom and WhatsApp by smartphone. It is logical. Most students come from low economy class. Therefore, they just purchased a smartphone with less adequate features with affordable price with low quality. It cannot accommodate online platforms, it worse when it can function well. No wonder students gave negative opinion (15.1\%). The location of campus STAIN Mandailing Natal is in a remote area. It affects the economy development and it grows a massive low-class economy.

The same condition is faced by students where they have serious problems on low-speed internet connection. Aspect of low-class economy and ability to have good Smartphone becomes surplus nightmare with the condition of low speed internet connection. It is rational that most students rated positive $(\mathrm{SA}=35.8 \%$ and $\mathrm{A}=47.2 \%)$ for question 11 on perception of the use of Zoom and WhatsApp face problems low speed internet connection. A very small number of them rated not problem $(3.8 \%)$, it cannot deny the majority.

Question 10 and 11 actually are correlated with question 12. Low quality of smartphone, low-speed internet connection, and the premier problem to cause them is low economy. This aspect was rated positive by students $(\mathrm{SA}=34 \%$ and $\mathrm{A}=43.4 \%)$. Total $78.4 \%$ of respondents agreed that the use of Zoom and WhatsApp is very difficult due to majority of students are coming from low economy class. The lowest percentage of disagree (1.8\%) implied that loweconomy class is serious problem that worsens the use of Zoom and WhatsApp in ELT.

Furthermore, based on open-ended questionnaire, most students agreed that internet bandwidth is main problem in the use of Zoom and WhatsApp in ELT. It is realistic due to the area of their campus is located at remote area. This is quite bothering to succeed the implementation of online learning. They mentioned that internet connection was bad and also they had limited internet data due to low economy class condition. Those problems caused the use of Zoom was not effective and the students could not listen well to the lecturer. Those answers of open-ended questionnaires strengthen the understanding that the use of Zoom and WhatsApp faced difficulties, especially unstable internet connection and owning limited 
internet data. It is expected that the government has good will to build the facilities of the availability of stable internet connection to support online learning system.

Students agreed that online learning system via Zoom and WhatsApp has a lot of advantages. One of advantages they mentioned was the use of Zoom and WhatsApp was effective and entertaining. For the matter of that, Zoom offers online face-to-face feature. It allows the students to feel as in the realistic classroom setting than in virtual class setting. Moreover, Zoom allows student directly gives a feedback, oral question and response in the middle of online learning. Fortunately, students felt like watching movie on Smartphone's screen rather than learning English. It steers the students into an entertaining atmosphere. In addition, students effectively can submit the assignment both written and spoken via WhatsApp features such as text messaging, voice notes, audio and video files and documents. It is very practical, saving time and energy and absolutely more economical. Some of students think by using Zoom and WhatsApp can improve their self-confidence, allow them to be more active to practice English and it allows them to access other supporting informative course materials sources at the same they are learning via online.

In other side, students also gave opinion that the uses of Zoom and WhatsApp in ELT have some disadvantages. The first disadvantage is bad signal of internet. It affected many things due to the use of Zoom and WhatsApp. They mentioned the bad internet bandwidth gives effect such as unclear voice in online platforms, bad delivered materials, lack of direct lecturer-students interaction, noisy and wasting a lot of internet quota.

Some students mentioned positive perception that the use of Zoom and WhatsApp is affordable in terms of saving time, more flexible, more effective and competitive. Moreover, some others rated it is not affordable in terms of internet data consumption, low economy class factor, and nasty signal of internet. The last, students decided that the use of Zoom and WhatsApp in ELT accommodates them into easier way of learning. They mentioned that the use of Zoom and WhatsApp is entertaining, simple, and flexible; it allows them to directly take part into virtual discussion. Some also mentioned that it does not accommodate their alternative learning method. The reasons were classical namely bad internet connection and consuming a lot of internet quota.

\subsection{Discussion of Students' Perception of the Use of Zoom and WhatsApp in ELT Amidst Covid19 Outbreak.}

Based on the findings in the previous pages, namely findings of the students' perception of the use of Zoom and WhatsApp in ELT amidst Covid19 outbreak, students perceived variously. Some decided positive attitudes and some other stood in the opposition. By all accounts, majority agreed that the use of Zoom and WhatsApp in ELT is positive. The quantitative findings are confirmed and clarified by qualitative findings where the results show that they are correlated. The main problem in the use of Zoom and WhatsApp in ELT is bad internet connection.

The students rated that the use of Zoom and WhatsApp can help them to understand English very well. They also agreed that virtual class via Zoom and WhatsApp is strategic for discussion, question-answer activity and task submission. It is in accordance to Cakrawati (2017) and Zamari, et.al (2011, pp.612) online system provides a lot of potentials and plays a significant role in language learning. Internet is accessible for both lecturer and learners. 
Online sources enable students to access documents and various other learning materials to support language acquisition. Moreover, the use of Zoom and WhatsApp is also rated saving money, energy and cost, mainly in using WhatsApp. For comparison, in virtual class setting, they need money for transportation from house to campus, money pocket for food and drink during around house-campus, much time allocation and energy. By Zoom and WhatsApp, all those costs are minimized. They only need money for internet data, no more. This is suitable with what Dweikat (2019, pp.18) stated that Whatsapp offers low cost service (cheap), includes since it is very easy, convenient, entertaining, reliable, and mostly used by 1,5 billion people around the world.

In addition, the use of Zoom and WhatsApp in ELT can help them to improve English skill and can increase their vocabulary mastery. During using these two online platforms, they operate with English terms and at the same time they directly can access online sources regarding their difficulties. This is in line with the findings of study from Wijayanti and Gunawan (2018) that revealed that online learning can increase students' vocabulary mastery. Moreover, the benefits of the use of Zoom and WhatsApp in ELT is that it can help students to practice English, make teaching-learning process more effective, and facilitate the lecturer-students interaction and communication. However, there are some disadvantages of the use of Zoom and WhatsApp. The dominant problems to apply them are bad internet connection, low economy class and lack of supporting facility for internet bandwidth, for instance free wifi at campus and around.

\section{Conclusion}

The study can be concluded that the virtual class of ELT for EFL University students in form of Zoom and WhatsApp was considered positive by the learners. Although the availability and slow speed internet connection were being problems to use them in ELT, they were also rated effective and efficient in terms of time, place and expense. Moreover, learners agreed that those two online platforms can help them to improve language skills and to reduce shyness in virtual class interaction.

Regarding to the findings of this study, the researcher suggests some recommendations regarding to the problem of internet connection, the campus, together with government must allocate a certain adequate budget to build some free WIFI service areas. Moreover, they also build supporting facilities, such as internet tower, and the like. Regarding to the low economy class, the students must be helped by providing aids in form interned data.

For upcoming research, the researcher hopes that the next researcher will widen the focus on larger scope, not only covering 53 respondents from two classes and two departments as in this study, but covering different universities and various regions: city and remote area. The researcher also hopes, the data collection is not restricted via closed-ended questionnaire and open-ended questionnaire only, but also oral interview. 


\section{References}

Abdillah, L. A., \& Darma, U. B. (2020). Online Learning Menggunakan Zoom Teleconference. in Wan Hassan, W.A.S., Ariffin, A., Ahmad, F., Hamzah, N., Rubani, S.N.K., Zakaria, N. (2020). Students' Perceptions Of Using Zoom Meet Webinar During Covid-19 Pandemic In Technical And Vocational Education. Journal of Critical Reviews. ISSN- 2394-5125 Vol 7, Issue 19, 2020.

Agung, A.S.S.N., Surtikanti, M.W., Quinones, C.A. (2020). Students' Perception of Online Learning during COVID-19 Pandemic: A Case Study on the English Students of STKIP Pamane Talino. SOSHUM Jurnal Sosial dan Humaniora [Journal of Social Sciences and Humanities] Volume 10, Number 2, 2020 p-ISSN. 2088-2262 e-ISSN. 2580-5622 ojs.pnb.ac.id/index.php.

Alvarez, M.C (2001). A Professor and his students - Share their thoughts, questions and feelings. Paper presented at the American Educational Research Association Annual Meeting, Seattle, Washington.

Armstrong, A.D. (2011). Students'Perceptions Of Online Learning And Instructional Tools: A Qualitative Study Of Undergraduate Students Use Of Online Tools. TOJET: The Turkish Online Journal of Educational Technology - July 2011, volume 10 Issue 3.

Bagata D.T.R., Umamah A., Fikri, D. (2020). EFL University Students' Perception of The Use of Online Learning Platform in The Covid 19 Pandemic. Jurnal Penelitian, Pendidikan dan Pembelajaran. Vol.15 No.34 (2020).

Cakrawati, L. M. (2017). Students' Perception on the Use of Online Learning Platform in EFL Classroom. English Language Teaching and Technology Journal (ELT-Tech Journal) Vol.1, No.1. http://ejournal.upi.edu/index.php/ELTTech/article/view/9428

Chen. (2003). Student Evaluation of Teaching Effectiveness: An Assessment of Student Perception and Motivation. Carfax Publishing.

Creswell, J.W. (2014). Research Design: Qualitative, Quantitative and Mixed-Method Approaches (fourth edition). Thousand Oaks, California: SAGE Publication Ltd.

Dweikat, K.A.J. (2019). EFL Students' Perceptions of WhatsApp and its Potential Benefits in ELT Practicum. Palestinian Journal of Technology and Applied Sciences - No.2, January 2019. DOI: https://doi.org/10.5281/zenodo.2582899

Farooq, R. (2018). How to Design and Frame Questionnaire. IGI Global, Indian Institute of Technology Guwahati. DOI: 10.4018/978-1-5225-3457-0.ch004

Khusniyah, M.L. (2020). Teacher's Perception on SQ4R in English Reading Comprehension Learning Using Zoom Application. VOLES: Voices of English Language Education Society. Vol.4, No.2; October 2020 E-ISSN 2579-7484 Pages 231-238. URL: http://dx.doi.org/10.29408/veles. v4i2.2554 
Mistar, I.B., (2016). Students' Perception on The Use of Whatsapp As A Learning Tool in ESL Classroom. Journal of Education and Social Sciences, Vol. 4, (June) ISSN 2289-9855.

Smart, K.L \& Cappel, J.J. (2006). Students' Perceptions of Online Learning: A Comparative Study. Journal of Information Technology Education, Volume 5, 2006. DOI: 1 $0.28945 / 243$ - Source: DBLP.

Susilawati, S. \& Supriyatno, T. 2020. Online Learning Through WhatsApp Group in Improving Learning Motivation in the Era and Post Pandemic COVID-19. Jurnal Pendidikan: Teori, Penelitian, dan Pengembangan, Vol.5, No.6 Bulan Juni Tahun 2020 Halaman: 852 - 859. http://journal.um.ac.id/index.php/jptpp/

Wahyuni, N., Nurpahmi, S., \& Awaliah, I.M. (2020). The Students' Perception Toward Using WhatsApp in Learning Reading. Presented at Proceeding of the 2nd International Conference on English Language Education (ICONELE) 2020, on September 14th - 15th, 2020 Virtual Conference Universitas Islam Negeri (UIN) Alauddin Makassar South Sulawesi-Indonesia.

Wijayanti, A., \& Gunawan, Y.B. (2018). Students' Perceptions Towards The Utilization Of "Whatsapp" For Vocabulary Teaching and Learning. ADJES (Ahmad Dahlan Journal of English Studies) Vol.5, No.2, September 2018, pp. 78-91 ISSN: 2477-2879 http://dx.doi.org/10.26555/adjes.v5i2. 10462.

Yee, R.C.S. 2011. Perception of Online Learning in An Australian University: Malaysian Students' Perspectives. Queensland University of Technology. Dissertation. Unpublished.

Zamari, ZM., Adnana, A.H.M, Idrisa SL, Yusofa J. (2012). Students' Perception of Using Online Language Learning Materials. Presented at: The 3rd International Conference on e-Learning ICEL 2011, 23-24 November 2011, Bandung, Indonesia. ProcediaSocial and Behavioral Sciences 67 (2012) 611 - 620. Published by Elsevier Ltd. doi: 10.1016/j.sbspro.2012.11.367 